\title{
Identification of GPAT acyltransferases in cork oak
}

\author{
Liliana Marum", Andreia Miguel, Pinto C Ricardo, Célia Miguel \\ From IUFRO Tree Biotechnology Conference 2011: From Genomes to Integration and Delivery \\ Arraial d Ajuda, Bahia, Brazil. 26 June - 2 July 2011
}

\section{Background}

Acyltransferases are enzymes with an important role in the synthesis of both cutin and suberin which are part of the lipophilic barriers, such as epidermis and periderm that protect terrestrial plants against water loss and other external aggressions. During secondary growth in woody plants such as cork oak (Quercus suber L.), the epidermis is replaced by a suberized periderm that includes the phellem (cork), phellogen (cork cambium) and phelloderm tissues. In Q. suber the successive formation of phellem following removal at periodic intervals (every 9 years) allows for exploitation of cork oak on a sustainable basis. The main component of cork (45-50\%) is suberin, a complex polymer comprising both aliphatic and aromatic domains and associated waxes $[1,2]$. Despite the physiological importance of suberin, its biosynthetic pathway as well as its deposition remains largely unknown. Since cork oak is a unique species among terrestrial plants due to its remarkable capacity for cork production, it is expected that suberin biosynthesis and deposition are tightly controlled mechanisms.

As a first step to start unraveling these control mechanisms we intend to identify and characterize genes coding for the acyltransferases of the GPAT (glycerol-3-phosphate acyltransferase) family, involved in suberin and cutin synthesis in cork oak. Two ESTs highly similar to GPAT5 (EE 743864 and EE 743865) and one EST (EE743668) highly similar to GPAT4 shown to be strongly up-regulated in the suberin-rich phellem of cork oak tree (Q. suber) were first identified by Soler et al. [3].

\footnotetext{
* Correspondence: marum@itab.unl.pt Instituto de Tecnologia Química e Biológica-Univ. Nova de Lisboa; Instituto de Biologia Experimental e Tecnológica (ITQB-UNL;IBET), Av. República, EAN, 2780-157 Oeiras, Portugal
}

(C) 2011 Marum et al; licensee BioMed Central Ltd. This is an open access article distributed under the terms of the Creative Commons Attribution License (http://creativecommons.org/licenses/by/2.0), which permits unrestricted use, distribution, and reproduction in any medium, provided the original work is properly cited. increasing age ( 1 to 7 years old) were harvested from cork oak and holm oak (a related but cork non-producing species)at the Instituto Superior de Agronomia (Portugal). Tissues collected during different growth periods were also used for analysis: samples collected during a period of high phellogen activity (April - June, 2009 and 2010) and samples collected during the inactive growth period (January, 2010). Total RNA was successfully extracted from these tissues using a protocol described by Reid et al. [4], with minor modifications. cDNA was synthesized using standard procedures and 5'- and 3'-RACE are being performed in order to determine the full-length of putative GPAT coding sequences from $Q$. suber transcriptome. The expression level of GPAT4 and GPAT5 genes was assessed by quantitative RT_PCR in two different seasonal stages (April and June) in periderm cells from 3 year old branches of $Q$. suber. The $\mathrm{Cp}$ values were converted into relative quantities, using the formula, $\mathrm{Q}=\mathrm{E}^{\Delta \mathrm{Cp}}$, where $\mathrm{E}$ (the efficiency of the gene amplification for each primer pair) was calculated using the Real-time PCR Miner algorithm.

\section{Results and conclusions}

A cDNA fragment with $1265 \mathrm{bp}$ of the putative Qs_GPAT5 was obtained. The predicted amino acid sequence displays the glycerol-3-phosphate acyltransferase (PLN02499) conserved domain. Based on a database search we have identified putative orthologs of $A t G$ PAT5 in P. trichocarpa (Pt_8s_AT, accession number 002312108; Pt_10s_AT, accession number 2315213) and $R$. communis (Rc_ERGPAT, accession number 2531580) genome, which show high similarity to the putative $Q$. suber GPAT5 gene. The Rc_ERGPAT is most similar to the Qs_GPAT5 with an identity of $83 \%$ at the amino acid level.
Material and methods
In this work, phellem tissues from small branches with \\ () Biomed Central}


The expression profiles of GPAT4 and GPAT5 were successfully analysed during phellem differentiation in periderm collected from cork oak tree. The relative expression level of GPAT4 gene was similar in April and June. However, the relative expression level of GPAT5 gene was higher in June, which corresponds to a period of higher phellogen activity, when compared to April.

Further information on the expression of these genes in several tissues of cork oak under different developmental stages and stress conditions will also be gathered as a result of the recent effort of the Portuguese research community involved in the transcriptome sequencing of cork oak. With this work we expect to contribute to elucidate basic aspects of the molecular networks involved in cork formation.

\section{Acknowledgements}

Fundação para a Ciência e Tecnologia (FCT) is acknowledged for support through the project SOBREIRO/0029/2009 and the grant SFRH/BPD/47679/ 2008.

Published: 13 September 2011

\section{References}

1. Graça J, Pereira H: The periderm development in Quercus suber. IAWA Journal 2004, 25:325-335.

2. Silva SP, Sabino MA, Fernandes EM, Correlo VM, Boesel LF, Reis RL: Cork: properties, capabilities and applications. International Materials Reviews 2005, 50:345-365.

3. Soler M, Serra O, Molinas M, Huguet G, Fluch S, Figueras M: A Genomic Approach to Suberin Biosynthesis and Cork Differentiation. Plant Physio 2007, 144:419-431.

4. Reid KE, Olsson N, Schlosser J, Peng F, Lund ST: An optimized grapevine RNA isolation procedure and statistical determination of reference genes for real-time RT-PCR during berry development. BMC Plant Biology $2006,6: 27$.

doi:10.1186/1753-6561-5-S7-P69

Cite this article as: Marum et al:: Identification of GPAT acyltransferases in cork oak. BMC Proceedings 2011 5(Suppl 7):P69.

\section{Submit your next manuscript to BioMed Central} and take full advantage of:

- Convenient online submission

- Thorough peer review

- No space constraints or color figure charges

- Immediate publication on acceptance

- Inclusion in PubMed, CAS, Scopus and Google Scholar

- Research which is freely available for redistribution

Submit your manuscript at www.biomedcentral.com/submit 